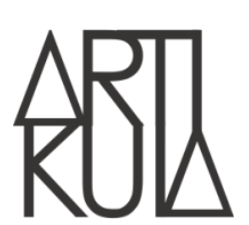

\title{
Penerapan Sistem E-Learning Melalui Aplikasi Edmodo dalam Meningkatkan Motivasi Belajar Mahasiswa Program Studi Pendidikan Bahasa, Sastra Indonesia dan Daerah di Universitas Mathla'ul Anwar Banten
}

\author{
Purlilaiceu $^{1}$
}

${ }^{1}$ Universitas Mathla'ul Anwar Banten

\begin{tabular}{l} 
ARTICLE INFO \\
\hline Article History: \\
Received 13.07.2018 \\
Received in revised \\
form 14.08.2018 \\
Accepted 19.09.2018 \\
Available online \\
27.09.2018
\end{tabular}

\begin{abstract}
This research was conducted to obtain data about how the application of elearning system through Edmodo application in improving student learning motivation in the language education program, Indonesian and regional literature at Universitas Mathla'ul Anwar Banten. The purpose of the study was to determine the effectiveness of the application of the e-learning system through the Edmodo application in improving student learning motivation. The methodology used in this study is descriptive analysis, meaning that the data obtained from the sample population of the study will be described and analyzed and then interpreted. In other words that analytical descriptive method is a method that aims to describe or give an overview of an object of research that is examined through samples or data that has been collected and make generally accepted conclusions. The sample data used in this study amounted to 56 students, while sampling was done using the "Random sampling" technique. The results obtained are through questionnaires distributed to students with the Google Drive application so that data can be obtained about student learning motivation with the e-learning system through the Edmodo application. The results of the study prove that student learning motivation is very high by using the e-learning system, it's just that the frequency of using Edmodo applications in learning must be improved.
\end{abstract}

Keywords: Edmodo Application, E-Learning System, Student Learning Motivation.

This is an open access article distributed under the terms of the Creative Commons Attribution 4.0 International License, which permits unrestricted use, distribution, and reproduction in any medium, provided the original work is properly cited. (c) 2018 Purlilaiceu.

\section{PENDAHULUAN}

Pendidikan di era globalisasi saat ini merupakan tantangan yang tidak dapat dielakkan lagi. Pengaruh yang sangat pesat telah membuktikan kepada kita semua bahwa globalisasi sebagai akibat berkembangnya teknologi informasi yang merupakan salah

${ }^{1}$ Corresponding author’s address: Universitas Mathla’ul Anwar Banten. Email: purlilaiceu83@gmail.com 
satu karakteristik abad ke-21 yang sangat signifikan. Seiring dengan perkembangan zaman, pendidikan pun menjadi salah satu ujung tombak dalam meningkatkan kualitas sumber daya manusia (SDM) agar dapat bersaing dalam kehidupan global di masa sekarang dan yang akan datang.

Di era revolusi industri sekarang ini telah membawa implikasi terhadap dunia pendidikan dan pembelajaran. Salah satu wujudnya adalah semakin tidak terbatasnya kebutuhan belajar maupun cara-cara memenuhi kebutuhan belajar. Belajar bukan lagi dilakukan dengan satu arah atau tatap muka dengan model konvensional, tetapi dapat juga dilakukan dengan cara cyber (maya, tidak nyata atau tidak terlihat). Maksudnya bahwa interaksi yang dilakukan oleh manusia tidak terbatas pada media, ruang dan waktu. Maka dari itu untuk menjawab tentangan tersebut dibutuhkan soft skill dan hard skill dalam mewujudkan Indonesia mandiri.

Seiring dengan perkembangan Teknologi Informasi yang semakin pesat, kebutuhan akan suatu konsep dan mekanisme dalam belajar-mengajar (pendidikan) berbasis teknologi informasi menjadi tidak terelakan lagi. Perkembangan sistem komputer melalui jaringan internet semakin meningkat, keberadaannya sangat diperlukan baik sebagai media informasi maupun komunikasi yang dilakukan secara bebas. Salah satu pemanfaatan internet adalah pada sistem pembelajaran jarak jauh melalui belajar secara elektronik atau yang lebih dikenal dengan istilah e-learning. Konsep yang terkenal dengan sebutan e-Learning ini membawa pengaruh terjadinya proses transformasi pendidikan konvensional ke dalam bentuk digital, baik secara isi dan sistemnya. Menurut Ardiansyah (2013:6) sistem e-learning adalah sistem pembelajaran yang digunakan sebagai sarana untuk proses belajar mengajar yang dilaksanakan tanpa harus bertatap muka secara langsung antara guru dengan siswa. Sistem e-Learning merupakan teknologi informasi dan komunikasi yang dimanfaatkan untuk pembelajaran jarak jauh, sistem pembelajaran yang tidak langsung dalam satu ruangan kelas sehingga tidak ada interaksi langsung secara tatap muka antara pengajar dan pembelajarnya.

Pemanfaatan e-learning tidak terlepas dari jasa internet khususnya dalam pembelajaran jarak jauh. Menurut Rusman (2012: 294) pemanfaatan e-learning antara lain:

1) Pengajar dan pembelajar dapat berkomunikasi secara mudah dengan cepat melalui fasilitas internet tanpa di batasi oleh jarak, tempat, dan waktu. Secara reguler atau kapan saja kegiatan berkomunikasi itu bisa dilakukan.

2) Pengajar dan pembelajar dapat menggunakan materi pembelajaran yang ruang lingkup dan urutan sudah sistematis terjadwal melalui internet, sehingga bagi pengajar bisa menilai seberapa jauh materi pembelajar tersebut dapat dipelajari dan dikuasainya.

3) Internet dapat dijadikan media untuk melakukan diskusi antara pengajar dan pembelajar, baik untuk seorang pembelajar, atau dalam jumlah pembelajar terbatas, bahkan masal.

4) Peran pembelajar menjadi lebih aktif mempelajari materi pembelajaran, memperoleh ilmu pengetahuan atau informasi secara mandiri tidak mengandalkan pemberian dari pengajar, disesuaikan pula dengan keinginan dan minatnya terhadap materi pembelajaran.

5) Relatif lebih efisien dari segi tempat, waktu, dan biaya.

Pembelajaran dapat diakses di mana saja, termasuk bagi pembelajar yang tinggal di daerah terpencil atau pedalaman yang jauh dari lembaga pendidikan, perguruan 
tinggi atau sekolah. Berkaitan dengan ruang atau tempat atau fasilitas e-learning tidak membutuhkan ruangan atau tempat yang luas sebagaimana ruang kelas konvensional, namun bisa dimana saja. Teknologi ini telah memperpendek jarak antara pengajar dan pembelajar.

Dengan perkembangan teknologi informasi dan komunikasi, interaksi antara pengajar dan pembelajar dapat dilakukan, baik dalam bentuk real time (waktu nyata) atau areal time (waktu tidak nyata). Pada sektor pendidikan perlunya melakukan inovatif dengan pemanfaatan teknologi sebagai dasarnya, Tantangan tersebut dapat terealisasikan dengan menerapkan aplikasi yang menunjang sistem pembelajaran mahasiswa melalui aplikasi Edmodo, dimana aplikasi Edmodo ini bertujuan untuk membantu pendidikan memanfaatkan fasilitas social networking. Edmodo adalah media sosial yang digunakan dalam dunia pendidikan yang biasa digunakan oleh guru, dosen, dan mahasiswa yang berfungsi untuk berbagai ide, file atau agenda kegiatan dan penugasan yang dapat menciptakan interaksi antara dosen dan mahasiswa, sehingga Edmodo memungkinkan bisa diterapkan sebagai media pembelajaran.

Edmodo dirancang untuk membuat mahasiswa bersemangat belajar di lingkungan yang lebih akrab. Di dalam Edmodo, dosen dapat melanjutkan diskusi kelas online, memberikan penilaian untuk memeriksa pemahaman mahasiswa, dan rancangan untuk dapat memberikan penghargaan kepada mahasiswa secara individual berdasarkan kinerja atau perilaku. Dalam pembelajaran Edmodo, dosen berada di tengah-tengah jaringan yang kuat yang menghubungkan dosen kepada mahasiswa, administrator, dan orang tua. Aplikasi Edmodo memiliki keunggulan diantaranya: menekankan atau mengkhususkan pada sistem pembelajaran, sangat mudah untuk digunakan, orang tua dapat mengontrol hasil belajar mahasiswa, dosen dan mahasiswa tidak harus bertatap muka secara langsung, dapat di akses siapa pun, kapan pun, dan dimana pun.

Adapun fungsi dari aplikasi Edmodo yaitu untuk mempermudah komunikasi antara mahasiswa dengan dosen, sebagai sarana komunikasi belajar atau berdiskusi, dan sebagai tempat untuk ujian atau kuis.Selain faktor eksternal yang mendukung dalam pembelajaran tentunya faktor internal bagian terpenting yang dapat membuktikan sejauhmana pembelajaran berhasil.Maka dari itu untuk mewujudkan pembelajaran yang maksimal dibutuhkan motivasi belajar yang tinggi dari mahasiswa, karena motivasi belajar menjadi modal awal dalam mewujudkan pembelajaran yang efektif dan efisien.Motivasi adalah usaha yang didasari untuk mengarahkan dan menjaga tingkah seseorang agar ia terdorong untuk bertindak melakukan sesuatu sehingga mencapai hasil atau tujuan tertentu.

Menurut Djamarah (2011: 148) motivasi belajar adalah suatu perubahan tenaga di dalam diri seseorang (pribadi) yang ditandai dengan timbulnya perasaan dan reaksi untuk mencapai tujuan. Motivasi belajar juga merupakan kebutuhan untuk mengembangkan kemampuan diri secara optimal, sehingga mampu berbuat yang lebih baik, berprestasi dan kreatif. Motivasi belajar adalah kondisi psikologis yang mendorong siswa atau mahasiswa untuk belajar secara sungguh-sungguh, yang pada gilirannya akan terbentuk cara belajar siswa yang sistematis, penuh konsentrasi dan dapat menyeleksi kegiatan-kegiatannya. Selain pengertian di atas tentunya motivasi memiliki tujuan. Menurut Purwanto (2010:73) tujuan dari motivasi adalah untuk menggerakkan atau menggugah seseorang agar timbul keinginan dan kemauannya untuk melakukan sesuatu sehingga dapat memperoleh hasil atau mencapai tujuan tertentu. Selain pengertian dan tujuan yang telah dipaparkan sebelumnya maka motivasi pun memiliki fungsi diantaranya: Pertama, mendorong manusia untuk berbuat. Jadi, sebagai penggerak atau 
motor yang melepaskan energi. Motivasi dalam hal ini merupakan motor penggerak dari setiap kegiatan yang akan dikerjakan. Kedua, menentukan arah perbuatan, yakni kearah tujuan yang hendak dicapai. Dengan demikian motivasi dapat memberikan arah dan kegiatan yang harus dikerjakan sesuai dengan rumusan tujuannya. Ketiga menyeleksi perbuatan, yakni menentukan perbuatan. Apa yang harus dikerjakan yang serasi guna mencapai tujuan, dengan menyisihkan perbuatan-perbuatan yang tidak bermanfaat bagi tujuan tersebut. Seorang siswa yang akan menghadapi ujian dengan harapan dapat lulus, tentu akan melakukan kegiatan belajar dan tidak akan menghabiskan waktunya untuk bermain kartu atau membaca komik, sebab tidak serasi dengan tujuan.

Disamping itu, ada juga fungsi-fungsi motivasi lain. Motivasi dapat juga sebagai pendorong usaha dan pencapaian prestasi. Seseorang melakukan suatu usaha karena adanya motivasi. Adanya motivasi yang baik dalam belajar akan menunjukkan hasil yang baik. Dengan kata lain, bahwa dengan adanya usaha yang tekun dan terutama didasari adanya motivasi, maka seseorang yang belajar itu akan dapat menyalurkan prestasi yang baik. Intensitas motivasi seorang siswa akan sangat menentukan tingkat pencapaian prestasi belajarnya.

Di dalam kegiatan belajar mengajar peran motivasi baik instrinsik maupun ekstrinsik sangat diperlukan. Motivasi bagi siswa dapat mengembangkan aktivitas dan mengarahkan serta memelihara ketekunan dalam melakukan kegiatan belajar. Adapun ciri-ciri motivasi belajar yaitu: tekun menghadapi tugas (dapat bekerja terus-menerus dalam waktu yang lama, tidak pernah berhenti sebelum selesai), ulet menghadapi kesulitan (tidak lekas putus asa) tidak memerlukan dorongan dari luar untuk berprestasi sebaik mungkin (tidak cepat puas dengan prestasi yang telah dicapainya),Lebih senang bekerja mandiri, cepat bosan pada tugas-tugas yang rutin (hal-hal yang bersifat mekanis, berulang-ulang begitu saja sehingga kurang aktif),dapat mempertahankan pendapatnya. (kalau sudah yakin akan sesuatu), tidak mudah melepaskan hal yang diyakini itu, senang mencari dan memecahkan maasalah soal-soal.

Apabila seseorang memiliki ciri-ciri seperti di atas, berarti seseorang itu memiliki motivasi yang cukup kuat. Ciri-ciri motivasi seperti itu akan sangat penting dalam kegiatan belajar mengajar. Dalam kegiatan belajar mengajar akan berhasil baik, jika siswa atau mahasiswa tekun mengerjakan tugas, ulet dalam memecahkan berbagai masalah dan hambatan secara mandiri.

\section{METODE}

Metodologi yang digunakan pada penelitian ini adalah deskriptif analisis, Maksud dari metode di atas yaitu data yang diperoleh dari sampel populasi penelitian akan dideskripsikan dan di analisis kemudian diinterpretasikan. Dengan kata lain bahwa metode deskriptif analitis merupakan metode yang bertujuan mendeskripsikan atau memberi gambaran terhadap suatu objek penelitian yang diteliti melalui sampel atau data yang telah terkumpul dan membuat kesimpulan yang berlaku umum. (Sugiyono, 2008 110).

Berdasarkan metode yang telah ditetapkan penulis,maka pengumpulan data yang dilakukan yaitu melalui angket secara online dengan menggunakan google drive. Adapun penggunaan angket penulis menentukan skala likert dengan skala 4, dengan bentuk pilihan yaitu selalu,sering, kadang-kadang, tidak pernah.Selain itu wawancara juga dilakukan untuk memperkuat dan mendukung data yang telah ada.Adapun angket yang 
disebarkan kepada mahasiswa yaitu tentang penerapan sistem e-learning melalui aplikasi Edmodo dalam meningkatkan motivasi belajar mahasiswa.

\section{Populasi}

Menurut Sugiyono (2008:115), populasi adalah wilayah generalisasi yang terdiri atas obyek atau subyek yang mempunyai kualitas karakteristik tertentu yang ditetapkan oleh peneliti untuk dipelajari dan kemudian ditarik kesimpulannya. Arikunto (2008:130) menjelaskan populasi adalah keseluruhan subjek penelitian. Berdasarkan penjelasan di atas, jadi populasi yang penulis teliti adalah seluruh mahasiswa Program Studi Pendidikan Bahasa, Sastra Indonesia dan Daerah di Universitas Mathla'ul Anwar Pandeglang Banten angkatan 2015 hingga 2017.

\section{Sampel}

Menurut Sugiyono (2008:116) "sampel adalah sebagian dari jumlah dan karakteristik yang dimiliki oleh populasi. Sedangkan Arikunto (2008: 131) mengatakan bahwa "sampel adalah bagian dari populasi yang diteliti". Adapun sampel dalam penelitian ini menggunakan teknik "Random sampling" dengan cara undian. Random sampling adalah teknik pengambilan sampel dimana semua individu dalam populasi baik secara sendirisendiri atau bersama-sama diberi kesempatan yang sama untuk dipilih sebagai anggota sampel.

\section{PEMBAHASAN}

Pada bab ini akan diuraikan hasil penelitian, yang terdiri atas deskripsi data, analisis data, interpretasi hasil penelitian. Data dalam penelitian ini diperoleh dari sampel yang berjumlah 56 orang mahasiswa. Pengumpulan data tersebut diperoleh dari hasil angket secara online dengan menggunakan google drive yang disebarkan secara acak kepada mahasiswa dengan menggali jawaban tentang motivasi belajar dengan sistem online melalui aplikasi Edmodo.

\section{Deskripsi dan Analisis Data}

Berdasarkan data hasil angket yang diperoleh tentang motivasi belajar, maka diperoleh data sebagai berikut. Angket yang diajukan kepada mahasiswa terdiri dari sepuluh pertanyaan terkait dengan motivasi belajar dengan sistem e-learning atau online melalui aplikasi Edmodo, serta menentukan pilihan jawaban yang dapat dipilih yaitu selalu, sering, kadang-kadang, dan tidak pernah.

Maka dari pertanyaan pertama yang diajukan tentang kesulitan belajar di kelas dengan sistem online. Dari 56 responden sebagian besar atau 62,5\% memilih jawaban kadang-kadang, 33,9\% menjawab tidak pernah, dan $0.5 \%$ menjawab selalu. Jadi dapat dikatakan bahwa sebagian besar mahasiswa kadang-kadang merasa kesulitan ketika harus belajar dengan media online tapi tidak sedikit yang merasa tidak memiliki kesulitan dalam belajar online. Berikut adalah penyajian data dari hasil angket mahasiswa. 
1. Apakah Anda merasa kesulitan ketika belajar di kelas dengan menggunakan media online?

56 tanggapan

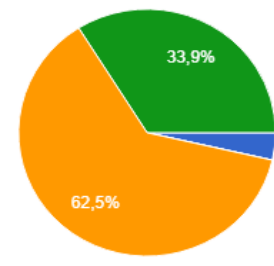

Pertanyaan kedua yang diajukan yaitu apakah mahasiswa mendiskusikan dengan teman-teman jika mengalami kesulitan belajar dengan online. Dari tanggapan responden terkait dengan pertanyaan angket kedua 21,8\% menjawab selalu, 36,4\% menjawab sering, $40 \%$ menjawab kadang-kadang. Dari hasil angket ke dua dapat dikatakan sebagian mahasiswa memiliki upaya untuk berdiskusi dan mempelajari kesulitan dalam belajar berbasis online. Berikut adalah penyajian data dari hasil angket mahasiswa.

2. Apakah anda mendiskusikan dengan teman-teman jika anda mengalami kesulitan belajar online?

55 tanggapan

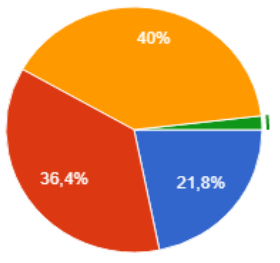

Pertanyaan angket selanjutnya yaitu menanyakan proses tanya jawab saat mahasiswa kesulitan mempelajari materi berbasis online, maka respon dari mahasiswa $32,7 \%$ menjawab selalu, $20 \%$ sering, 38,2\% kadang-kadang, dan 9,1\% tidak pernah. Maka dari hasil jawaban mahasiswa dapat peroleh kesimpulan bahwa mereka memiliki keingintahuan yang lebih ketika belajar dengan media online meskipun ada beberapa yang menjawab kadang-kadang, bisa mereka sudah memiliki dasar kemampuan dengan menggunakan medi online. Berikut adalah penyajian data dari hasil angket mahasiswa.

3. Apakah anda bertanya pada dosen bila anda kurang jelas dalam menerima materi pelajaran berbasis online?

55 tanggapan

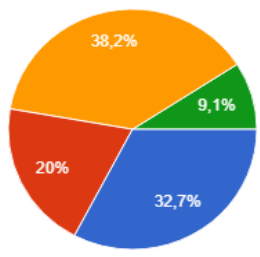


Pertanyaan ke empat tentang upaya mahasiswa yang bertanya pada orang lain jika mendapatkan kesulitan dalam pembelajaran online, maka respon jawaban mahasiswa $35,7 \%$ menjawab selalu, 35,7\% menjawab sering, dan 25\% menjawab kadang-kadang. Berdasarkan hasil angket yang diperoleh dapat dikatakan bahwa ada usaha dan kemauan dari mahasiswa untuk bertanya kepada orang lain atau dosen yang dianggap lebih mampu untuk mempelajari kesulitan dalam belajar online. Berikut adalah penyajian data dari hasil angket mahasiswa.

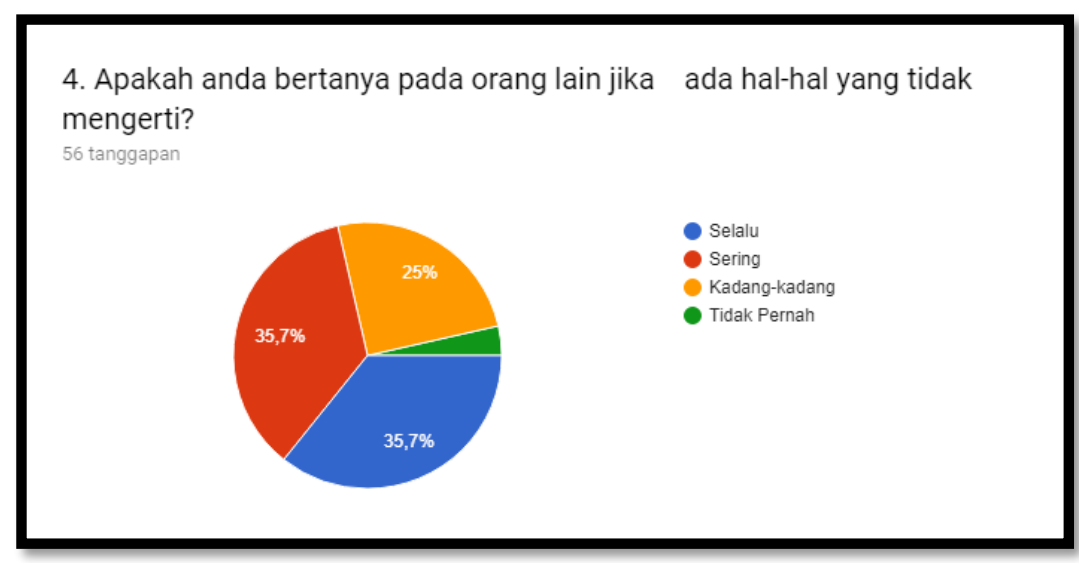

Pertanyaan kelima mengenai senang atau tidaknya mahasiswa menggunakan sistem pembelajaran di kelas dengan menggunakan media online. Jawaban responden adalah 26,8 menjawab selalu, 16,1\% menjawab sering, 55,4\% menjawab kadang-kadang. Berdasarkan jawaban angket mahasiswa sebagian besar mereka menjawab kadangkadang artinya bahwa sebagian jawaban dari mereka pasti dilatarbelakangi oleh faktorfaktor kepemilikan perangkat atau hardware/laptop/notebook sehingga menjadi kendala mereka dalam mengakses atau menggunakan media online. Berikut adalah penyajian data dari hasil angket mahasiswa.

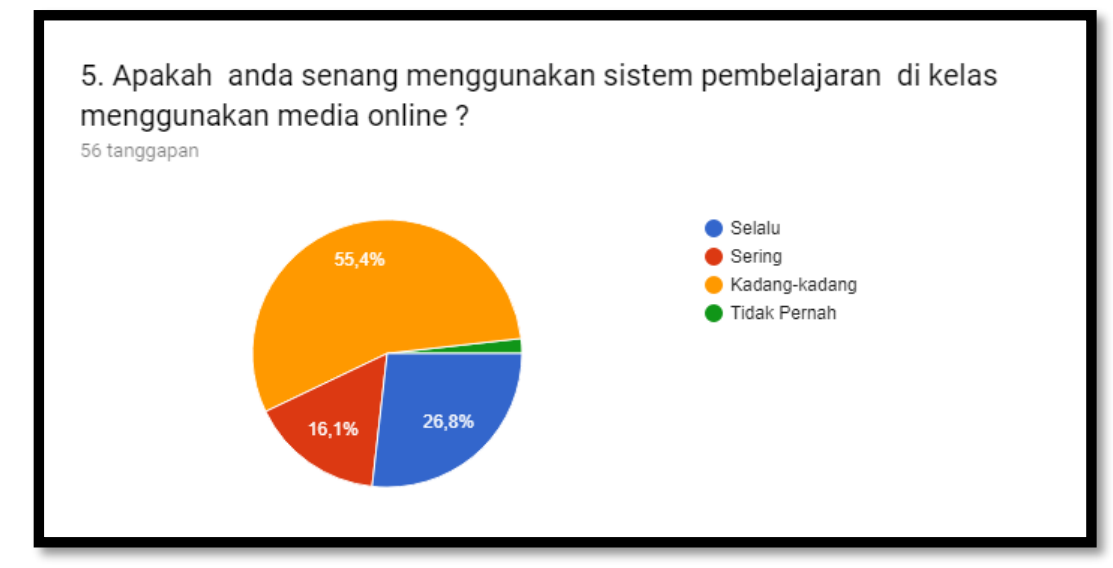

Pertanyaan keenam menanyakan kesulitan mahasiswa jika pembelajaran di kelas menggunakan media online. Maka respon dari jawaban mahasiwa $71,4 \%$ menjawab kadang-kadang, 19,6 menjawab tidak pernah. Maka dapat dikatakan bahwa sebagian besar dari mahasiswa merasakan kesulitan ketika menggunakan media online karena mereka tidak terbiasa diarahkan untuk menggunakan media tersebut. tetapi sebagian dari mahasiswa justru mereka tidak pernah mengalami kesulitan dalam belajar online. Maka dari itu pembelajaran berbasis computer atau e-learning harus dibiasakan. Berikut adalah penyajian data dari hasil angket. 
6. Apakah anda merasa kesulitan jika pembelajaran di kelas menggunakan media online

56 tanggapan

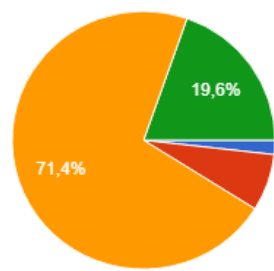

Pertanyaan ketujuh menanyakan tentang pernah tidaknya mahasiswa menggunakan aplikasi media online khususnya Edmodo, maka jawaban dari mahasiswa 23,2\% kadangkadang, dan 76,8 tidak pernah. Jadi dapat dikatakan bahwa sebagai besar dari mahasiswa belum mengenal aplikasi Edmodo artinya aplikasi tersebut belumlah familiar di tengatengah mereka.Meskipun sebagi kecil dari mahasiswa sudah mengetahui aplikasi tersebut. Berikut adalah penyajian data dari hasil angket.

7. Apakah anda menggunakan aplikasi media online khususnya edmodo ? 56 tanggapan

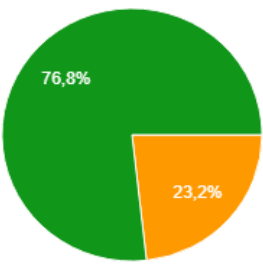

Pertanyaan kedelapan menanyakan tentang apakah mahasiswa menghindari mata kuliah yang dianggap sulit, maka hasil responden $21,4 \%$ kadang-kadang, dan 78,6\% tidak pernah. Jadi dapat dikatakan bahwa mahasiswa akan terus berusahan dan berupaya dalam meningkatkan kemampuannya dalam belajar meskipun sebagin kecil dari mahasiswa menghindarinya. Berikut adalah penyajian data dari hasil angket.

8. Apakah anda menghindari mata kuliah yang dianggap sulit ?

56 tanggapan

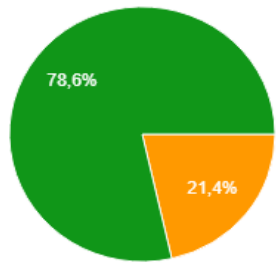

Pertanyaan kesembilan menanyakan tentang persiapan mahasiswa ketika mengikuti pembelajaran di kelas, maka hasilnya adalah $60,7 \%$ selalu mempersiapkan, 10,7\% sering, 23,2\% kadang-kadang. Maka dari hasil respon mahasiswa bahwa sebagian besar dari 
mahasiswa memiliki keantusiasan dalam belajar serta memiliki keinginan untuk meningkatkan kompetensi diri. Berikut adalah penyajian data dari hasil angket.

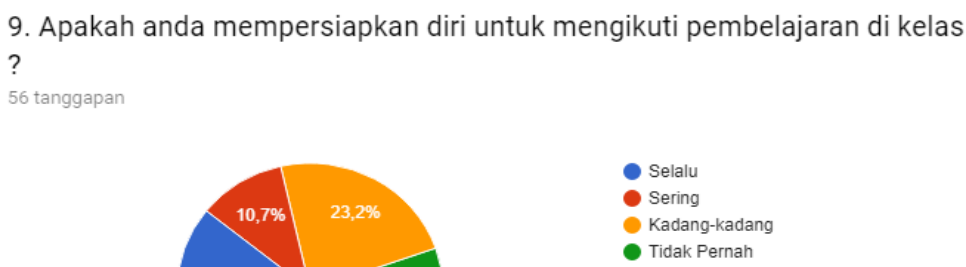

Pertanyaan kesepuluh tentang apakah penyampaian materi secara online dapat meningkatkan kemampuan belajar mahasiswa. Hasil responden adalah 25\% selalu, 10,7\% sering, 62,5 kadang-kadang. Maka hasil dari angket dapat disimpulkan bahwa latar belakang kemampuan mahasiswa yang bervariasi turut mempengaruhi kegiatan belajar online. Tetapi sebagian dari mahasiwa yang lain tidak mendapatkan kesulitan pada saat belajar online. Berikut adalah penyajian data dari hasil angket.

10. Apakah penyampaian materi dengan cara online membuat anda dapat meningkatkan kemampuan belajar?

56 tanggapan

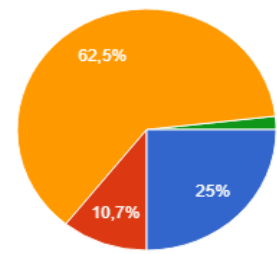

\section{SIMPULAN}

Berdasarkan hasil analisis data penelitian, tentang tanggapan responden mengenai pembelajaran e-learning melalui aplikasi Edmodo maka dapat disimpulan bahwa adanya motivasi belajar yang tinggi dari mahasiswa dengan menggunakan sistem e-learning hanya saja frekuensi penggunaan aplikasi Edmodo dalam pembelajaran harus lebih ditingkatkan. Dapat penulis katakan juga bahwa penyebab kendala-kendala yang lain turut menjadi alasan dalam penggunaan sistem e-learning dengan aplikasi Edmodo ini seperti faktor sumber daya manusia (SDM), faktor lingkungan, dan faktor infrastruktur. Selain itu penulis juga dapat menyimpulkan bahwa penerapan sistem e-learning ini dapat menjawab tantangan di era revolusi yang akandatang. Jadi salah satu alternatif yang dapat digunakan oleh pengajar atau dosen adalah penerapan sistem e-learning dengan aplikasi Edmodo perlu ditingkatkan. Selain sangat mudah diterapkan, aplikasi Edmodo berguna bagi proses pembelajaran berbasis e-learning.hal yang harus diperhatikan dosen dan mahasiswa yaitu harus memiliki fasilitas yang mendukung untuk proses belajar tersebut agar pencapaian tujuan pembelajaran dapat berhasil dan meningkat. 


\section{REFERENSI}

Arikunto, S. (2010). Prosedur penelitian (Suatu pendekatan praktek). Jakarta: Rineka Cipta.

Arikunto, S. (2005). Dasar-dasar evaluasi pendidikan. Jakarta: Bumi Aksara.

Djamarah, S. B. (2011). Psikologi belajar. Jakarta: Rineka Cipta.

Munir. (2009). Pembelajar jarak jauh berbasis teknologi informasi dan komunikasi. Bandung: Alfabeta.

Purwanto, M. N. (2010). Psikologi pendidikan. Bandung: Remaja Rosdakarya.

Rusman. (2011). Model-model pembelajaran (Mengembangkan profesionalisme guru). Jakarta: Raja Grafindo Persada.

Rusman. (2012). Belajar dan pembelajaran berbasis komputer. Bandung: Alfabeta.

Sugiyono. (2011). Metode penelitian kombinasi (Mixed methods). Bandung: Alfabeta.

Warsita, B. (2008). Teknologi pembelajaran; Landasan dan aplikasinya. Jakarta: Rineka Cipta.

Yamin, M. (2011). Paradigma baru pembelajaran. Jakarta: Gaung Persada. 